\title{
Purposive Sampling as a Tool for Informant Selection
}

\author{
Ma. Dolores C. Tongco
}

\section{Research Methods}

\begin{abstract}
Informant selection is highly relevant for ethnobotanical research, as people are constantly looked upon for knowledge and information. The purposive sampling technique is a type of non-probability sampling that is most effective when one needs to study a certain cultural domain with knowledgeable experts within. Purposive sampling may also be used with both qualitative and quantitative research techniques. The inherent bias of the method contributes to its efficiency, and the method stays robust even when tested against random probability sampling. Choosing the purposive sample is fundamental to the quality of data gathered; thus, reliability and competence of the informant must be ensured.
\end{abstract}

\section{Introduction}

Data gathering is crucial in research, as the data is meant to contribute to a better understanding of a theoretical framework (Bernard 2002). It then becomes imperative that selecting the manner of obtaining data and from whom the data will be acquired be done with sound judgment, especially since no amount of analysis can make up for improperly collected data (Bernard et al. 1986).

Purposive sampling is an informant selection tool widely used in ethnobotany (Table 1). However, the use of the method is not adequately explained in most studies. The purposive sampling technique, also called judgment sampling, is the deliberate choice of an informant due to the qualities the informant possesses. It is a nonrandom technique that does not need underlying theories or a set number of informants. Simply put, the researcher decides what needs to be known and sets out to find people who can and are willing to provide the information by virtue of knowledge or experience (Bernard 2002, Lewis \& Sheppard 2006). Purposive sampling is especially exemplified through the key informant technique (Bernard 2002, Gar- cia 2006, Gustad et al. 2004, Jarvis et al. 2004, Lyon \& Hardesty 2005), wherein one or a few individuals are solicited to act as guides to a culture. Key informants are observant, reflective members of the community of interest who know much about the culture and are both able and willing to share their knowledge (Bernard 2002, Campbell 1955, Seidler 1974, Tremblay 1957).

This paper focuses on how to go about selecting people willing to impart their knowledge and experiences with plants through the purposive sampling method of informant selection. Examples of studies that have used purposive sampling are given, including the type of population sampled, data gathering techniques, analyses done and key results. Concerns regarding the validity of this nonrandom technique and the reliability of an informant are also tackled in this paper.

\section{Using the Purposive Sampling Method}

In choosing a sampling method for informant selection, the question the researcher is interested in answering is of utmost importance. The question will decide the objectives on which the methodology will be based. The first

\section{Correspondence}

Ma. Dolores C. Tongco, Department of Botany, University of Hawai' i at Manoa, 3190 Maile Way, Honolulu, HI, 96822 U.S.A. and Institute of Biology, University of the Philippines, Diliman, Quezon City, 1101, PHILIPPINES

mdctongco@gmail.com

Ethnobotany Research \& Applications 5:147-158 (2007) 
Table 1. Purposive Sampling Used in Ethnobotanical Atudies. Three categories: Studies of specific skills, knowledge, or practices; Comparisons between practices; and Case studies.

\begin{tabular}{|c|c|c|c|c|c|}
\hline \multicolumn{6}{|c|}{ Studies of specific skills, knowledge, or practices } \\
\hline Research Problem & Methods & Population Sampled & Sample & Analyses & Citation \\
\hline $\begin{array}{l}\text { Cultural significance } \\
\text { of plants }\end{array}$ & $\begin{array}{l}\text { Unstructured } \\
\text { interviews }\end{array}$ & $\begin{array}{l}\text { Informants } \\
\text { chosen based on } \\
\text { traditional ecological } \\
\text { knowledge, } \\
\text { residency, } \\
\text { professional } \\
\text { activity, age }\end{array}$ & 54 people & $\begin{array}{l}\text { Index of } \\
\text { cultural } \\
\text { significance }\end{array}$ & $\begin{array}{l}\text { Silva \& } \\
\text { Andrade } 2006\end{array}$ \\
\hline $\begin{array}{l}\text { Collect information } \\
\text { on almost-forgotten } \\
\text { plant uses }\end{array}$ & Interviews & $\begin{array}{l}\text { Elders with empirical } \\
\text { knowledge }\end{array}$ & $\begin{array}{l}132 \text { people } \\
\text { in } 60 \\
\text { outlying } \\
\text { villages }\end{array}$ & none specified & $\begin{array}{l}\text { Tardio et } \\
\text { al. } 2005\end{array}$ \\
\hline $\begin{array}{l}\text { Use and availability } \\
\text { of craft vines }\end{array}$ & $\begin{array}{l}\text { Semi-structured } \\
\text { interviews, direct } \\
\text { observations }\end{array}$ & $\begin{array}{l}\text { Persons involved } \\
\text { in basket-weaving } \\
\text { activities }\end{array}$ & 66 people & Percentages & $\begin{array}{l}\text { Martinez- } \\
\text { Romero et } \\
\text { al. } 2004\end{array}$ \\
\hline $\begin{array}{l}\text { Sustainability and } \\
\text { use of gara dyeing }\end{array}$ & Field interviews & Gara dyers & $\begin{array}{l}\text { none } \\
\text { specified }\end{array}$ & none specified & McFoy 2004 \\
\hline $\begin{array}{l}\text { Use of } \\
\text { hemiepiphytes } \\
\text { in craftmaking }\end{array}$ & $\begin{array}{l}\text { Interviews, } \\
\text { participant } \\
\text { observation }\end{array}$ & $\begin{array}{l}\text { Male craftmaking } \\
\text { and hemiepiphyte } \\
\text { collector specialists }\end{array}$ & $\begin{array}{l}\text { none } \\
\text { specified }\end{array}$ & none specified & $\begin{array}{l}\text { Vargas \& van } \\
\text { Andel } 2005\end{array}$ \\
\hline $\begin{array}{l}\text { Construction of } \\
\text { a clapperstick }\end{array}$ & $\begin{array}{l}\text { Unstructured } \\
\text { interviews, } \\
\text { participant } \\
\text { observation }\end{array}$ & $\begin{array}{l}\text { Female clapperstick- } \\
\text { makers }\end{array}$ & 2 people & none specified & $\begin{array}{l}\text { Walker et } \\
\text { al. } 2004\end{array}$ \\
\hline $\begin{array}{l}\text { How edible wild } \\
\text { plants are used }\end{array}$ & $\begin{array}{l}\text { Focus group } \\
\text { discussion }\end{array}$ & $\begin{array}{l}\text { Peasant association } \\
\text { based on relatively } \\
\text { heterogeneous } \\
\text { agroecology }\end{array}$ & 6-8 people & none specified & $\begin{array}{l}\text { Addis et } \\
\text { al. } 2005\end{array}$ \\
\hline $\begin{array}{l}\text { Knowledge and } \\
\text { valuation of wild } \\
\text { food plants }\end{array}$ & $\begin{array}{l}\text { Key informant, } \\
\text { semi-structured } \\
\text { interviews, } \\
\text { informal interviews }\end{array}$ & $\begin{array}{l}\text { Informants chosen } \\
\text { based on knowledge } \\
\text { of wild food plants }\end{array}$ & $\begin{array}{l}\text { none } \\
\text { specified }\end{array}$ & none specified & Garcia 2006 \\
\hline $\begin{array}{l}\text { Names and uses } \\
\text { of edible wild } \\
\text { mushrooms }\end{array}$ & $\begin{array}{l}\text { Key informants, } \\
\text { interviews, }\end{array}$ & Mushroom collectors & $\begin{array}{l}\text { none } \\
\text { specified }\end{array}$ & none specified & $\begin{array}{l}\text { Jarvis et } \\
\text { al. } 2004\end{array}$ \\
\hline $\begin{array}{l}\text { Medicinal properties } \\
\text { of food in Buddhist } \\
\text { temples }\end{array}$ & $\begin{array}{l}\text { Interviews, } \\
\text { questionnaires }\end{array}$ & $\begin{array}{l}\text { Cooks in Buddhist } \\
\text { temples }\end{array}$ & $\begin{array}{l}\text { at least } 2 \\
\text { in each of } \\
27 \text { temples }\end{array}$ & Percentages & Kim et al. 2006 \\
\hline $\begin{array}{l}\text { Documentation } \\
\text { of traditional } \\
\text { healing practices }\end{array}$ & Interviews & Traditional healers & $\begin{array}{l}\text { none } \\
\text { specified }\end{array}$ & none specified & $\begin{array}{l}\text { Hammiche \& } \\
\text { Maiza } 2006\end{array}$ \\
\hline $\begin{array}{l}\text { Contemporary } \\
\text { traditional healing }\end{array}$ & $\begin{array}{l}\text { Key informants, } \\
\text { interviews, }\end{array}$ & $\begin{array}{l}\text { Healers with good } \\
\text { reputations }\end{array}$ & 8 people & Qualitative & $\begin{array}{l}\text { Lyon \& } \\
\text { Hardesty } 2005\end{array}$ \\
\hline $\begin{array}{l}\text { Herbs used in } \\
\text { medicinal baths }\end{array}$ & Interviews & $\begin{array}{l}\text { Herbalists, } \\
\text { elderly villagers, } \\
\text { local healers }\end{array}$ & $\begin{array}{l}\text { none } \\
\text { specified }\end{array}$ & Percentages & Li et al. 2006 \\
\hline $\begin{array}{l}\text { Uses of Atuna } \\
\text { racemosa Raf. }\end{array}$ & Interviews & $\begin{array}{l}\text { Locals that utilized } \\
\text { and harvested oil } \\
\text { from Atuna racemosa }\end{array}$ & 6 people & Use frequency & Prance 2004 \\
\hline
\end{tabular}




\begin{tabular}{|c|c|c|c|c|c|}
\hline \multicolumn{6}{|c|}{ Studies of specific skills, knowledge, or practices } \\
\hline Research Problem & Methods & Population Sampled & Sample & Analyses & Citation \\
\hline $\begin{array}{l}\text { Ethno- } \\
\text { pharmacological } \\
\text { survey }\end{array}$ & $\begin{array}{l}\text { Interviews, } \\
\text { questionnaires }\end{array}$ & $\begin{array}{l}\text { Healers of } \\
\text { schistosomiasis }\end{array}$ & 40 people & $\begin{array}{l}\text { Univariate } \\
\text { analysis, } \\
\text { Pearson chi- } \\
\text { square, cross- } \\
\text { tabulation, } \\
\text { percentages }\end{array}$ & Bah et al. 2006 \\
\hline $\begin{array}{l}\text { Information on } \\
\text { medicinal plants }\end{array}$ & Interviews & $\begin{array}{l}\text { Locals } \\
\text { knowledgeable } \\
\text { in medicinal } \\
\text { plant usage }\end{array}$ & $\begin{array}{l}\text { none } \\
\text { specified }\end{array}$ & none specified & Brussell 2004 \\
\hline $\begin{array}{l}\text { Determine antifungal } \\
\text { properties of plants } \\
\text { traditionally used in } \\
\text { fungal infections }\end{array}$ & $\begin{array}{l}\text { Interviews, } \\
\text { questionnaires }\end{array}$ & $\begin{array}{l}\text { Traditional healers } \\
\text { of fungal infections }\end{array}$ & 14 people & none specified & $\begin{array}{l}\text { Hamza et } \\
\text { al. } 2006\end{array}$ \\
\hline $\begin{array}{l}\text { Use of medicinal } \\
\text { plants }\end{array}$ & Interviews & $\begin{array}{l}\text { Patients based on } \\
\text { medical history }\end{array}$ & $\begin{array}{l}\text { none } \\
\text { specified }\end{array}$ & none specified & $\begin{array}{l}\text { Ramihanta- } \\
\text { niariyo et } \\
\text { al. } 2003\end{array}$ \\
\hline $\begin{array}{l}\text { Use of medicinal } \\
\text { plants in Candida } \\
\text { infections }\end{array}$ & Interviews & $\begin{array}{l}\text { Traditional healers for } \\
\text { Candida infections }\end{array}$ & $\begin{array}{l}\text { none } \\
\text { specified }\end{array}$ & none specified & $\begin{array}{l}\text { Runyoro et } \\
\text { al. } 2006\end{array}$ \\
\hline $\begin{array}{l}\text { Use of medicinal } \\
\text { plants for } \\
\text { dermatology }\end{array}$ & Interviews & $\begin{array}{l}\text { Healers or families } \\
\text { with tradition of } \\
\text { healing, knowledge } \\
\text { about skin ailments } \\
\text { and cosmetics }\end{array}$ & $\begin{array}{l}\text { None } \\
\text { specified }\end{array}$ & Frequencies & $\begin{array}{l}\text { Saikia et } \\
\text { al. } 2006\end{array}$ \\
\hline $\begin{array}{l}\text { Role of Cannabis in } \\
\text { cigarette smoking }\end{array}$ & Interviews & $\begin{array}{l}\text { Informants chosen } \\
\text { based on Cannabis } \\
\text { and cigarette history }\end{array}$ & 59 people & none specified & Highet 2004 \\
\hline $\begin{array}{l}\text { Comparison of } \\
\text { ethnoveterinary } \\
\text { medicines for } \\
\text { racehorses }\end{array}$ & Interviews & Livestock farmers & 60 people & none specified & $\begin{array}{l}\text { Lans et al. } \\
2006\end{array}$ \\
\hline $\begin{array}{l}\text { Preferences of } \\
\text { farmers in selecting } \\
\text { shade trees }\end{array}$ & $\begin{array}{l}\text { Informal } \\
\text { interviews, } \\
\text { questionnaires }\end{array}$ & $\begin{array}{l}\text { Small-scale farmers } \\
\text { with experience } \\
\text { regarding } \\
\text { shade trees }\end{array}$ & 83 people & $\begin{array}{l}\text { Frequencies, } \\
\text { chi-square }\end{array}$ & $\begin{array}{l}\text { Albertin \& } \\
\text { Nair } 2004\end{array}$ \\
\hline $\begin{array}{l}\text { Potential for } \\
\text { sustainable } \\
\text { harvesting }\end{array}$ & $\begin{array}{l}\text { Interviews, direct } \\
\text { observations, } \\
\text { freelisting }\end{array}$ & $\begin{array}{l}\text { Carpenters, } \\
\text { harvesters, foresters, } \\
\text { households, store } \\
\text { owners, merchants }\end{array}$ & $\begin{array}{l}\text { at least } 18 \\
\text { people }\end{array}$ & Percentages & Anderson 2004 \\
\hline $\begin{array}{l}\text { Cacao farmers' } \\
\text { understanding } \\
\text { regarding } \\
\text { shade trees }\end{array}$ & $\begin{array}{l}\text { Semi-structured } \\
\text { interviews, survey }\end{array}$ & Cacao farmers & 21 people & none specified & $\begin{array}{l}\text { Bentley et } \\
\text { al. } 2004\end{array}$ \\
\hline $\begin{array}{l}\text { Use and value of } \\
\text { tree products }\end{array}$ & $\begin{array}{l}\text { Key informants, } \\
\text { interviews, }\end{array}$ & $\begin{array}{l}\text { Buyers or sellers of } \\
\text { market tree products }\end{array}$ & 43 people & none specified & $\begin{array}{l}\text { Gustad et } \\
\text { al. } 2004\end{array}$ \\
\hline $\begin{array}{l}\text { Use of landscape } \\
\text { visualization in } \\
\text { forest management } \\
\text { involving indigenous } \\
\text { groups }\end{array}$ & Interviews & $\begin{array}{l}\text { Informants chosen } \\
\text { based on criteria } \\
\text { of knowledge, role } \\
\text { in community and } \\
\text { communication skills }\end{array}$ & 11 people & none specified & $\begin{array}{l}\text { Lewis \& } \\
\text { Sheppard } 2006\end{array}$ \\
\hline
\end{tabular}




\begin{tabular}{|l|l|l|l|l|l|}
\hline \multicolumn{3}{|l|}{ Studies of specific skills, knowledge, or practices } \\
\hline Research Problem & Methods & Population Sampled & Sample & Analyses & Citation \\
\hline $\begin{array}{l}\text { Evaluation of trees } \\
\text { for reforestation } \\
\text { and agroforestry }\end{array}$ & $\begin{array}{l}\text { Interviews, listing, } \\
\text { categorizing }\end{array}$ & $\begin{array}{l}\text { Informants chosen } \\
\text { based on gender, } \\
\text { farm, location, } \\
\text { farm activity }\end{array}$ & 27 people & none specified & $\begin{array}{l}\text { McDonald } \\
\text { et al. } 2003\end{array}$ \\
\hline $\begin{array}{l}\text { Use of poisonous } \\
\text { plants as } \\
\text { insecticides }\end{array}$ & $\begin{array}{l}\text { Interviews, } \\
\text { participant- } \\
\text { observation }\end{array}$ & $\begin{array}{l}\text { Specialists } \\
\text { representative for } \\
\text { each area and } \\
\text { ecological region }\end{array}$ & $\begin{array}{l}\text { none } \\
\text { specified }\end{array}$ & none specified & $\begin{array}{l}\text { Orozco \& } \\
\text { Lentz 2005 }\end{array}$ \\
\hline
\end{tabular}

\begin{tabular}{|c|c|c|c|c|c|}
\hline \multicolumn{6}{|c|}{ Comparisons between practices } \\
\hline Research Problem & Methods & Population Sampled & Sample & Analyses & Citation \\
\hline $\begin{array}{l}\text { Comparison of four } \\
\text { land-use options }\end{array}$ & $\begin{array}{l}\text { Interviews, survey, } \\
\text { focus group } \\
\text { discussion }\end{array}$ & Farmers & $\begin{array}{l}10 \text { for each } \\
\text { livelihood } \\
\text { strategy for } \\
\text { each of } 3 \\
\text { villages }\end{array}$ & $\begin{array}{l}\text { Analysis of } \\
\text { variance, } \\
\text { benefit-cost } \\
\text { ratio, returns } \\
\text { to labor, } \\
\text { sensitivity } \\
\text { analysis, net } \\
\text { present value }\end{array}$ & $\begin{array}{l}\text { Belcher et } \\
\text { al. } 2004\end{array}$ \\
\hline $\begin{array}{l}\text { Evaluation of } \\
\text { a subsistence } \\
\text { farming system }\end{array}$ & Survey & $\begin{array}{l}\text { Farmers from project } \\
\text { vs. non-project farms }\end{array}$ & $\begin{array}{l}223 \\
\text { households }\end{array}$ & Percentages & $\begin{array}{l}\text { Neupane \& } \\
\text { Thapa } 2001\end{array}$ \\
\hline $\begin{array}{l}\text { Impacts of } \\
\text { various factors } \\
\text { on agroforestry }\end{array}$ & Survey & $\begin{array}{l}\text { Farmers from project } \\
\text { vs. non-project farms, } \\
\text { also depending on } \\
\text { whether farms had } \\
\text { exotic species }\end{array}$ & $\begin{array}{l}223 \\
\text { households }\end{array}$ & $\begin{array}{l}\text { Logistic } \\
\text { regression } \\
\text { models }\end{array}$ & $\begin{array}{l}\text { Neupane et } \\
\text { al. } 2002\end{array}$ \\
\hline $\begin{array}{l}\text { Use of a plant as } \\
\text { an insecticide }\end{array}$ & Questionnaires & $\begin{array}{l}\text { Vegetable farmers } \\
\text { who used and did not } \\
\text { use a particular plant } \\
\text { as an insecticide }\end{array}$ & 32 people & Percentages & $\begin{array}{l}\text { Tran \& Perry } \\
2003\end{array}$ \\
\hline
\end{tabular}

\begin{tabular}{|c|c|c|c|c|c|}
\hline \multicolumn{6}{|l|}{ Case studies } \\
\hline Research Problem & Methods & Population Sampled & Sample & Analyses & Citation \\
\hline $\begin{array}{l}\text { If farmers perceive } \\
\text { forests positively } \\
\text { or negatively }\end{array}$ & $\begin{array}{l}\text { Focus group } \\
\text { discussion used } \\
\text { to construct a } \\
\text { questionnaire } \\
\end{array}$ & Farmers & 20 people & none specified & $\begin{array}{l}\text { Dolisca et } \\
\text { al. } 2007\end{array}$ \\
\hline $\begin{array}{l}\text { How indigenous } \\
\text { communities deal } \\
\text { with ecological } \\
\text { variability and } \\
\text { managing } \\
\text { common areas }\end{array}$ & Interview & Berry harvesters & 45 people & none specified & $\begin{array}{l}\text { Parlee \& } \\
\text { Berkes } 2006\end{array}$ \\
\hline $\begin{array}{l}\text { Sustainability } \\
\text { of management } \\
\text { practices }\end{array}$ & Questionnaire & $\begin{array}{l}\text { Communes chosen } \\
\text { based on geography, } \\
\text { socioeconomics and } \\
\text { farming practices }\end{array}$ & \begin{tabular}{|l}
270 \\
households
\end{tabular} & none specified & $\begin{array}{l}\text { Zhen et } \\
\text { al. } 2006\end{array}$ \\
\hline
\end{tabular}


consideration is whether to study the entire population, and if not, how to sample the population efficiently. How many people will be involved? What level of organization would be sampled-individual or community? What sampling technique should be used to assure the sample is representative and the data collected replicable, solid and relevant (Alexiades 1996, Bernard 2002)? The researcher must then decide if purposive sampling is the most suitable tool for the study.

If so, the researcher is ready to seek out appropriate informants (Box 1). Preparation is needed in that one must know about the culture before one samples the population in order to find knowledgeable and reliable informants most efficiently (Snedecor 1939). Asking help from the community would be useful at this point. For instance, Bah et al. (2006) visited a village head to inquire about traditional healers. The sample can also be taken from knowledge from previous studies (McDonald et al. 2003). One way of deciding how to choose informants is described by Allen (1971). Criteria are set on what would make a good informant, and what would make a bad informant. Based on these, a list of qualifications is composed. It is especially important to be clear on informant qualifications when using purposive sampling (Allen 1971). The conditions for the desired informant may be very specific, as in Hammiche and Maiza (2006) who wanted to study traditional healers that are known outside family and friend circles, and who share their knowledge patrilineally, are professionals, somewhat nomadic, and former nomads who have become tourist guides due to familiarity with the landscape. The informant must also be as near as possi- ble to the theoretical norm of the sampled population (e.g. as close as possible to the typical woodcarver), and able to communicate often with other people of his or her craft (Allen 1971, Lewis \& Sheppard 2006).

Showing the list of qualifications to resource people who can help find informants will save much time and effort that can be brought about by misunderstanding (Allen 1971, Bernard et al. 1986). To add a quantitative twist, resource persons may be asked to individually name the eight most appropriate informants. The best informant would be the person who was mentioned most times by multiple resource persons. For example, informant $A$ was mentioned in four out of eight interviews. This is the highest frequency and so the informant must be good. However, the informant becomes more qualified if he was the only one mentioned four times, as opposed to a situation wherein ten people are mentioned four times. Two factors are being sought after here: the frequency of mention, and the rarity of frequently-mentioned individuals. The goal is to find someone frequently mentioned the most number of times (Sanders 1960).

Purposive sampling can be used with a number of techniques in data gathering (Godambe 1982). A study may be started with a survey, then purposive sampling done based on the survey (Brown 2005). Robbins et al. (1969) used a questionnaire as a systematic way to find informants in a study about acculturation. The researchers asked the respondents what would denote acculturation and ran their responses through a data reduction technique to determine which qualities acculturated people

Box 1. Steps in purposive sampling.

1. Decide on the research problem.

2. Determine the type of information needed.

- Information from every individual in the community is potentially valuable $>$ use random sampling o Time and resources are too limited for random sampling > use purposive sampling with caution

- Information is held by only certain members of the community > use purposive sampling o Information needs a high degree of interpretation regarding cultural significance $>$ use key informants

3. Define the qualities the informant(s) should or should not have.

4. Find your informants based on defined qualities.

- Research about the area and community.

- Ask for help before going to the site and upon arrival at the site.

- Realize finding informants may be a trial and error process. Be patient and persistent!

5. Keep in mind the importance of reliability and competency in assessing potential informants.

6. Use appropriate data gathering techniques.

7. In analyzing data and interpreting results, remember that purposive sampling is an inherently biased method.

- Document the bias.

- Do not apply interpretations beyond the sampled population. 
were likely to have. They then set out to find informants with these traits. Data reduction techniques are statistical tools that select from multiple variables those that have the greatest effect on a phenomenon. Factor analysis and ordination are examples of these techniques (Manly 1994). Sometimes snowball sampling, which is asking an informant to suggest another informant, follows purposive sampling (Brown 2005, Tran \& Perry 2003). Snowball sampling differs from purposive sampling in that purposive sampling does not necessarily use the source of an informant as an informant as well (Bernard 2002). Stratified purposive sampling may also be used, wherein a purposive subsample is chosen within a purposive sample (Belcher et al. 2006). Key informants have also been used to find purposive samples (Barany 2006). Both random and purposive sampling may also be combined to produce a powerful way of sampling (Albertin \& Nair 2004, Godambe 1982), such as when Zhen et al. (2006) purposively chose four communes to study how farmers managed their areas in China. Within each commune, they randomly chose one village per commune to which they administered questionnaires.

However the informant is found and chosen, the method must be reproducible in order for the results to contribute to a greater understanding of ethnobotanical theories and phenomena (Hones 1990). One way of ensuring reproducibility is to have a systematic way of choosing the informant and to describe this method in detail. The list of qualifications is helpful in reproducibility. The idea is that somebody who visits the community and conducts the same study should be able to produce similar results. When the selection of informants is not mentioned (Bussman 2006, Banack et al. 2004, Delang 2005, Ross-lbarra \& Molina-Cruz 2002, Sundriyal \& Sundriyal 2004), reproducibility of the study is reduced, and readers may also be led to question the robustness of the data.

There is no cap on how many informants should make up a purposive sample, as long as the needed information is obtained (Bernard 2002). Seidler (1974) studied different sample sizes of informants selected purposively and found that at least five informants were needed for the data to be reliable. It is important to lessen bias within the sampling population and to have some idea of the variation in the data. If unbiased informants are scarce, finding informants that are biased in both ways allow for finding the middle ground and canceling out extreme biases during data interpretation (Seidler 1974).

Both qualitative and quantitative sampling methods may be used when samples are chosen purposively (Table 1, Campbell 1955), such as participant-observation studies (Walker et al. 2004), ranking activities, questionnaires (Zhen et al. 2006), participatory mapping (Parlee \& Berkes 2006), direct observations (Martinez-Romero et al. 2004) and interviews (Anderson 2004, Li et al. 2006, Ramihantaniariyo et al. 2003). Statistical analyses such as logis- tic regression models (Neupane et al. 2002), frequencies, chi-square (Albertin and Nair 2004), analysis of variance (Belcher et al. 2004), univariate analysis and cross tabulation (Bah et al. 2006), among others, have also been used with purposive sampling.

\section{Examples of Purposive Sampling in Ethnobotany}

Purposive sampling has been used through the years (Campbell 1955, Godambe 1982) and is currently actively employed in ethnobotany (Lewis \& Sheppard 2006, McDonald et al. 2003, McFoy 2004, Neupane \& Thapa 2001, Neupane et al. 2002, Orozco \& Lentz 2005). Purposive sampling can be applied to research in a number of ways (Table 1), such as in preliminary studies where the researcher is still testing the feasibility of a proposed study (Poggie 1972), sampling informants with a specific type of knowledge or skill (Li et al. 2006, Prance 2004, Vargas \& van Andel 2005), comparisons of cultural practices (Neupane et al. 2002), case studies (Dolisca et al. 2007, Parlee \& Berkes 2006), and when the population is too small for a random sample (Tran \& Perry 2003). The following examples show the context in which purposive sampling has been used, discussing the problem, research method, and results obtained from the study. It is hoped that these examples, together with Table 1, will aid a researcher in deciding the appropriateness of purposive sampling to a particular study.

Walker et al. (2004) studied how the Acjachemen women of California made a clapperstick out of Mexican elderberry (Sambucus mexicana C. Presl, Caprifoliaceae). The clapperstick is a musical instrument that is played with songs and has high cultural significance. Participant-observation and unstructured interviews of two skillful women revealed that the construction of the clapperstick was done in three steps which was harvesting, shaping, and decorating. It was also found that throughout the years, the tools used in making the clapperstick had changed, yet the cultural meaning and rituals attached to the clapperstick remained intact.

Tran and Perry (2003) determined how and why farmers used neem (Azardirachta indica var. siamensis Valenton, Meliaceae) as an insecticide in Thailand. Pesticide poisoning had been a problem in the country, and natural means of preventing insect pests that were non-toxic to humans were in demand. To study the use of neem as an insecticide, survey questionnaires were administered to two groups: farmers who used neem as insecticides and farmers who did not. The neem-using farmers were chosen purposively as they were too few (32) to be sampled randomly. Farmers who did not use neem were selected using snowball sampling. Sixteen non-neem users were found. The authors discovered that the differences between the neem and non-neem groups were largely 
awareness-based. The non-neem groups did not receive training though they had heard of the insecticide properties of neem. The efficacy of powdered neem was also tested, which turned out to be low, because the active ingredient would degrade when exposed to the sun and humid and warm conditions. Proper processing and storage was needed. While some farmers used neem available from the government, others processed their own. It was recommended that the village have a neem-processing plant in order to have enough resources for all farmers.

Dolisca et al. (2007) dealt with how farmers perceived a forest reserve in Haiti as a case study to test the theory that local people would be more willing to conserve an area if they were to benefit from it. A survey was first done to find out the socio-economic profile of the people in the area using pre-tested questionnaires and random informant selection. Purposive sampling was then used to select farmers to participate in focus group discussions. Based on the results of the focus group discussions, a questionnaire was constructed wherein villagers were asked to rank the importance of each benefit derived from conservation. Since benefits run on multiple dimensions, factor analysis was used to determine the dimensions which affect farmers' perceptions most. The farmers were found to prefer economic and environmental benefits, with tourism ranking highest. The study revealed that the farmers were environmentally aware. This was in contrast to the government's perception that local people were against conservation. Working with local people may in fact be better for conservation in this community as it would incorporate their concerns into an integrated conservation plan that would benefit all.

Garcia (2006) studied the transmission of knowledge from mother to child regarding wild food plants in the Paniya tribe of India in the context of economic advancements and interaction with non-tribal groups. She also considered the presence of an educational program that aimed to increase cultural identity and knowledge of local biodiversity in the area and compared children enrolled in the program with children who went to a more conventional school. All students of the educational program were included in the study. Children who were not part of the educational program, as well as the mothers in the study, were selected opportunistically based on availability. Elders were also used as key informants that could provide information on how the knowledge about and gathering of wild food plants had changed over time. Wild food plants were not gathered as much because there were fewer of them. It was also found that knowledge about wild food plants was decreasing because the children went to school instead of accompanying their mothers in gathering these plants. However, children in the educational program were able to learn about the wild food plants in school. Mothers also seemed to be conveying contradicting perceptions regarding wild food plants. Children were taught that wild food plants were healthy and medicinal, yet consumption of these wild food plants may be a cause for shame because the non-tribal people looked down on consumption of wild food plants as a sign of poverty. Elders also mentioned that the children seemed to be going through a change in food preferences as they were exposed to other types of food sold in the markets.

The above examples illustrate an array of ways purposive sampling has been used in ethnobotanical studies, in conjunction with different research methods and problems. This type of sampling is most applicable when studying aspects of a culture not known to all its members. In every culture, there are certain people who know much more than the average person when it comes to certain cultural domains (Campbell 1955, Tremblay 1957, Zelditch 1962) such as traditional healing. In this case, it is more practical to talk to a specialist rather than a random individual from the culture (Bernard 2002). Purposive samples are especially useful in documenting events that not everyone can attend or witness, including secret events that some people in the community may not even be aware of (Zelditch 1962). The key informant technique can also be used to study cultures that are unreachable or unapproachable, especially earlier cultures that no longer exist (Seidler 1974).

\section{Purposive Sampling as a Valid Nonrandom Method}

Whenever possible and deemed efficient, random or probability sampling is recommended as a means of informant selection because randomization reduces biases and allows for the extension of results to the entire sampling population (Godambe 1982, Smith 1983, Snedecor 1939, Topp et al. 2004), Results may also be applied beyond the community studied (Bernard 2002, Godambe 1982, Karmel \& Jain 1987). However, random sampling is not always feasible, and not always efficient. A high dispersion of samples may induce higher costs for a researcher (Alexiades 1996, Bernard 2002, Snedecor 1939). Missing data, which is common in field situations, also renders random samples invalid for traditional probabilistic statistical inference (Godambe 1982). This often occurs because not everybody is willing to participate, and possibly not be around during sampling (Alexiades 1996). Gomez-Beloz (2002) randomly chose informants among men who were willing to participate in his study and encountered respondents that suddenly became unavailable when he was ready to administer his survey. Some respondents also did not answer all items in questionnaires, and so new informants were needed to be found.

Unlike random sampling, non-probability methods such as purposive sampling are not free from bias. Informants may be chosen out of convenience or from recommendations of knowledgeable people (Lopez et al. 1997, Seidler 1974, Smith 1983, Zelditch 1962). However, data collect- 
ed from purposive sampling may still be valid for certain studies. When a sample is representative, it becomes valid over the realm it represents, providing external validity. When a sample is measured correctly, it becomes valid for the sample, thus providing internal validity. Non-probability methods contribute more to internal validity than external validity. In purposive sampling, interpretation of results is limited to the population under study. To be valid over a greater realm or to form the basis for a theory, the study may be repeated for confirmation in a different population, still using a non-probability method (Bernard 2002). It is important to state the bias clearly when the results are analyzed and interpreted so as not to mislead people into inferring general conclusions (Bernard 2002, Godambe 1982, Snedecor 1939).

Despite its inherent bias, purposive sampling can provide reliable and robust data. The strength of the method actually lies in its intentional bias (Bernard 2002, Lewis \& Sheppard 2006, Poggie 1972, Tremblay 1957). Campbell (1955) conducted a study wherein he took purposive samples and compared these with a survey of all crew members regarding morale. Results of both methods were highly correlated using Spearman rank order correlation. Karmel and Jain (1987) compared the results of a model-based purposive sampling method and a random sample with the intention of advocating random sampling. To their surprise, the purposive method did better than the random method, encouraging statisticians to look beyond random sampling designs. Topp et al. (2004) also did a study comparing purposive and random techniques in a study involving users of the drug ecstasy. They found that their purposive sample approximated a random sample of the population.

Though recognized as a tool in the social sciences, purposive sampling is conceptually used in the natural sciences as well, such as in ecology. As in ethnobotany, the choice of method would depend on the question the researcher is asking and the objectives to be met (Kenkel et al. 1989). For example, in seeking to eradicate invasive species, an area with high abundance of these invasives would be sought and sampled (Rew et al. 2006). Time and accessibility may also be concerns, as certain areas may be restricted or difficult to sample (Bourdeau 1953, Kenkel et al. 1989). Sampling randomly may also exclude the very units that the researcher may want to sample, especially if the units are distributed patchily across an area (Bourdeau 1953, Danz et al. 2005). Nonrandom sampling designs include systematic sampling, wherein the first point is random but all succeeding samples are a certain distance from the first and all samples are spread evenly apart (Bourdeau 1953). Stratified random sampling can also be used, wherein certain areas are chosen, and samples are randomly sampled within the areas (Bourdeau 1953, Danz et al. 2005). This is equivalent to finding informants purposively, and then choosing informants randomly within the purposive sample.
There are different ways of sampling, and non-probability methods can be just as good as probability methods in some situations. To insist on randomized samples every time is to run the danger of losing efficiency and failing to recognize the existence of different types of information which can be extracted from a community in more than one way (Zeidlitch 1962). Purposive sampling, when used appropriately, is more efficient than random sampling in practical field circumstances (Bernard 2002, Karmel \& Jain 1987) because the random member of a community may not be as knowledgeable and observant as an expert informant (Tremblay 1957). This method is especially useful when there is not enough funds and other resources (Campbell 1955, Karmel \& Jain 1987, Topp et al. 2004). Purposive sampling can be more realistic than randomization in terms of time, effort and cost needed in finding informants (Seidler 1974, Snedecor 1939).

\section{Informant Reliability}

The danger with the purposive method is that the researcher exercises judgment on the informant's reliability and competency. This is a relevant concern especially regarding key informants on whom much of the data quality rest. It is critical to be certain of the knowledge and skill of the informant when doing purposive sampling, as inappropriate informants will render the data meaningless and invalid (Godambe 1982). The researcher must also be alert for possible biases on the part of the informant (Seidler 1974).

Reliability involves how consistent the information is across the community (Alexiades 1996) and may be thought of as a ratio of the number of correct and incorrect pieces of information from an informant (Giedymin 1963, Lopez et al. 1997, Medin et al. 1997, Reyes-Garcia et al. 2005, Romney 1999, Romney et al. 1986, Ross and Medin 2005, Zent 2001). Informants may give unreliable data voluntarily or involuntarily because they are eager to please, may have hidden purposes and intentions and have their own emotional issues, principles, and viewpoints (Alexiades 1996, Bernard et al. 1986). When data appears to be incoherent and implausible, cross-checking and validation methods such as triangulation may be done to verify certain ideas and concepts (Alexiades 1996, Sanders 1960, Seidler 1974, Tremblay 1957). Quality control should always be part of the study proposal and budget, as it is expected the researcher will run into some inconsistencies in data that need to be verified. A trip back to the field site near the end of the study is highly recommended to clean up these inconsistencies as much as possible (Sanders 1960).

The researcher should also know how to ask appropriate questions that would draw out the information being sought (Zelditch 1962). Reliability of informants tends to be higher for objective data than subjective data (Seidler 1974). 
Poggie (1972) tested the use of one informant each from seven Mexican communities (350-3000 inhabitants per community) versus a probability-based survey. He found that the results obtained from the informants correlated with the results of the survey at correlation coefficients of 0.05-0.90 depending on the question. Informants approximated survey results when the questions concerned facts or openly observed phenomena such as how many people worked in an area. However, the more private and personal a question was, or the more the answers were based on opinions, the informants were less accurate in approximating survey results. The manner of interviewing, conditions during the interview, and how comfortable the informant is with the researcher may also affect reliability (Alexiades 1996, Bernard et al. 1986).

Reliable informants may not necessarily be competent, however. Reliability refers to how honest and truthful the informant is, while competency involves how qualified the person is to answer questions about the cultural domain the researcher is studying. The Cultural Consensus Model (CCM) may be used to determine competency of an informant and is useful for finding the most competent informants for further interaction (Bernard 2002). CCM is described in detail at http://www.analytictech.com/borgatti/consensu.htm.

\section{The Practice of Purposive Sampling}

Through continued use of techniques, the researcher learns how to choose informants efficiently and wisely, and to choose the level of analysis necessary to answer certain objectives (Bernard 2002). As one becomes more familiar with a method, a higher skill level is expected to be obtained (Bridges \& Lau 2006). Purposive sampling is one such skill that needs to be used and practiced so as to be optimal. Perhaps in the beginning, the researcher would still be groping through the method, knowing the concepts but still a bit indecisive and apprehensive. After a while though, rules start to break down, and experience and intuition take over. Based on both the question and the community of study, the expert purposive sampler will intuitively know if purposive sampling is applicable, how to find informants, where to find informants, how many informants are needed, and how to correctly assess reliability and credibility of an informant. Expertise can only be achieved by constant practice and integrating many experiences.

Experts in purposive sampling are encouraged to discuss and discover ways of finding the best type of informant (and how many) for each research question, as well as the strengths and weaknesses of these methods. Methodologies regarding measurements with informants, solutions for dealing with shortcomings of informant selection processes, and tests concerning dependability and strength of informant selection techniques are also needed (Campbell 1955, Seidler 2004).

\section{Conclusion}

In ethnobotanical research, the fact that humans are involved necessitates the use of informants, and methods in informant selection need to be actively discussed. Purposive sampling is a practical and efficient tool when used properly, and can be just as effective as, and even more efficient than, random sampling. More studies focusing on the use of purposive sampling would be welcome in the ethnobotanical literature.

\section{Acknowledgements}

I would like to thank Dr. Will McClatchey, Dr. Kim Bridges, Summer Austin, Leyla Cabugos, Rebekah Fuller, Tim Gallaher, Bruce Hoffman and Laura Weiss from the Botany Department of the University of Hawai i for insightful comments on the drafts of this manuscript.

\section{Literature Cited}

Addis, G., K. Urga \& D. Dikassol. 2005. Ethnobotanical study of edible wild plants in some selected districts of Ethiopia. Human Ecology 33:83-118.

Albertin, A. \& P.K.R. Nair. 2004. Farmers' perspectives on the role of shade trees in coffee production systems: an assessment from the Nicoya Peninsula, Costa Rica. Human Ecology 32:443-463.

Alexiades, M.N. 1996. Editor of Selected Guidelines for Ethnobotanical Research: A field manual. The New York Botanical Garden, New York.

Allen, H.B. 1971. Principles of informant selection. American Speech 46:47-51.

Anderson, P.J. 2004. The social context for harvesting Iriartea deltoidea (Arecaceae). Economic Botany 58:410419.

Bah, S., D. Diallo, S. Demb'el'e \& B.S. Paulsen. 2006. Ethnopharmacological survey of plants used for the treatment of schistosomiasis in Niono District, Mali. Journal of Ethnopharmacology 105:387-399.

Banack, S.A., X.J. Rondon \& W. Diaz-Huamanchumo. 2004. Indigenous cultivation and conservation of totora (Schoenoplectus californicus, Cyperaceae) in Peru. Economic Botany 58:11-20.

Barany, M.E. 2006. Non-timber forest products in the livelihood and coping strategies of households and communities afflicted by HIVIAIDS. Masters thesis. Virginia Poly- 
technic Institute and State University, Blacksburg, Virginia, USA.

Belcher, B., Rujehan, N. Imang \& R. Achdiawan. 2004. Rattan, rubber, or oil palm: cultural and financial considerations for farmers in Kalimantan. Economic Botany 58: S77-S87.

Bentley, J.W., E. Boa \& J. Stonehouse. 2004. Neighbor trees: shade, intercropping, and cacao in Ecuador. $\mathrm{Hu}$ man Ecology 32:241-270.

Bernard, H.R. 2002. Research Methods in Anthropology: Qualitative and quantitative methods. 3rd edition. AltaMira Press, Walnut Creek, California.

Bernard, H.R., P.J. Pelto, O. Werner, J. Boster, A.K. Romney, A. Johnson, C.R. Ember \& A. Kasakoff. 1986. The construction of primary data in cultural anthropology. Current Anthropology 27: 382-396.

Bourdeau, P.F. 1953. A test of random versus systematic ecological sampling. Ecology 34:499-512.

Bridges, K. \& Y.H. Lau. 2006. The skill acquisition process relative to ethnobotanical methods. Ethnobotany $R e-$ search and Applications 4:115-118.

Brown, K.M. 2006. Reconciling moral and legal collective entitlement: Implications for community-based land reform. Land Use Policy 2:4.

Brussell, D.E. 2004. Amedicinal plant collection from Montserrat, West Indies. Economic Botany 58:S203-S220.

Bussman, R.W. 2006. Ethnobotany of the Samburu of Mt. Nyiru, South Turkana, Kenya. Journal of Ethnobiology and Ethnomedicine doi:10.1186/1746-4269-2-35.

Campbell, D.T. 1955. The informant in quantitative research. The American Journal of Sociology 60:339-342.

Danz, N.P., R.R. Regal, G.J. Niemi, V.J. Brady, T. Hollenhorst, L.B. Johnson, G.E. Host, J.M. Hanowski, C.A. Johnston, T. Brown, J. Kingston \& J.R. Kelly. 2005. Environmentally stratified sampling design for the development of Great Lakes environmental indicators. Environmental Monitoring and Assessment 102:41-65.

Delang, C.O. 2005. The market for medicinal plants in Sapa and Hanoi, Vietnam. Economic Botany 59:377-385.

Dolisca, F., J.M. McDaniel \& L.D. Teeter. 2007. Farmers' perceptions towards forests: A case study from Haiti. Forest Policy and Economics 9:704-712.

Garcia, G.S.C. 2006. The mother - child nexus: knowledge and valuation of wild food plants in Wayanad, West- ern Ghats, India. Journal of Ethnobiology and Ethnomedicine 2:39.

Giedymin, J. 1963. Reliability of informants. The British Journal for the Philosophy of Science 13:287-302.

Godambe, V.P. 1982. Estimation in survey sampling: robustness and optimality. Journal of the American Statistical Association 77:393-403.

Gomez-Beloz, A. 2002. Plant use knowledge of the Winikina Warao: the case for questionnaires in ethnobotany. Economic Botany 56:231-241.

Gustad, G., S.S. Dhillion \& D. Sidibe. 2004. Local use and cultural economic value of products from trees in the parklands of the municipality of Cinzana, Mali. Economic Botany 58:578-587.

Hammiche, V. \& K. Maiza. 2006. Traditional medicine in Central Sahara: pharmacopoeia of Tassili N'ajjer. Journal of Ethnopharmacology 105:358-367.

Hamza, O.J.M, C. J.P. van den Bout-van den Beukel, M.I.N. Matee, M.J. Moshi, F.H.M. Mikx, H.O. Selemani, Z.H. Mbwambo, A.J.A.M. Van der Ven \& P.E. Verweij. 2006. Antifungal activity of some Tanzanian plants used traditionally for the treatment of fungal infections. Journal of Ethnopharmacology 108:124-132.

Highet, G. 2004. The role of cannabis in supporting young people's cigarette smoking: a qualitative exploration. Health Education Research 19:635-643.

Hones, M.J. 1990. Reproducibility as a methodological imperative in experimental research. Proceedings of the Biennial Meeting of the Philosophy of Science Association 1:585-599.

Jarvis, M.C., A.M. Miller, J. Sheahan, K. Ploetz, J. Ploetz, R.R. Watson, M.P. Ruiz, C.A.P. Villapan, J.G. Alvarado, A.L. Ramirez \& B. Orr. 2004. Edible wild mushrooms of the Cfre de Perote Region, Veracruz, Mexico: an ethnomycological study of common names and uses. Economic Botany 58:S111-S115.

Karmel, T.S. \& M. Jain. 1987. Comparison of purposive and random sampling schemes for estimating capital expenditure. Journal of the American Statistical Association 82:52-57.

Kenkel, N.C., P. Juhasz-Nagy \& J. Podani. 1989. On sampling procedures in population and community ecology. Vegetatio 83:195-207.

Kim H., M.-J. Song \& D. Potter. 2006. Medicinal efficacy of plants utilized as temple food in traditional Korean Buddhism. Journal of Ethnopharmacology 104:32-46. 
Lans, C., N. Turner, G. Brauer, G. Lourenco \& K. Georges. 2006. Ethnoveterinary medicines used for horses in Trinidad and in British Columbia, Canada. Journal of Ethnobiology and Ethnomedicine 2:31.

Lewis, J.L. \& S.R.J. Sheppard. 2006. Culture and communication: can landscape visualization improve forest management consultation with indigenous communities? Landscape and Urban Planning 77:291-313.

Li, S., C. Long, F. Liu, S. Lee, Q. Guo, R. Li \& Y. Liu. 2006. Herbs for medicinal baths among the traditional Yao communities of China. Journal of Ethnopharmacology 108:5967.

Lopez, A., S. Atran, J.D. Coley, D.L. Medin \& E.E. Smith. 1997. The tree of life: universal and cultural features of folkbiological taxonomies and inductions. Coginitive Psychology 32:251-295.

Lyon, L.M. \& L.H. Hardesty. 2005. Traditional healing in the contemporary life of the Antanosy people of Madagascar. Ethnobotany Research and Applications 3:287-294.

Manly, B.F.J. 1994. Multivariate Statistical Methods: $A$ primer. 2nd edition. Chapman and Hall/CRC Press, New York.

Martinez-Romero, M.M., A.E. Castro-Ramirez, P. Macario \& J.C. Fernandez. 2004. Use and availability of craft vines in the influence zone of the biosphere reserve Sian Kaan Quintana Roo, Mexico. Economic Botany 58:83-97.

McDonald, M.A., A. Hofny-Collins, J.R. Healey \& T.C.R. Goodland. 2003. Evaluation of trees indigenous to the montane forest of the Blue Mountains, Jamaica for reforestation and agroforestry. Forest Ecology and Management 175:379-401.

McFoy, C. 2004. Ethnobotany and sustainable utilization of natural dye plants in Sierra Leone. Economic Botany 58:S66-S76.

Medin, D.L., E.B. Lynch, J.D. Coley \& S. Atran. 1997. Categorization and reasoning among tree experts: do all roads lead to Rome? Cognitive Psychology 32:49-96.

Neupane, R.P. \& G.B. Thapa. 2001. Impact of agroforestry intervention on soil fertility and farm income under the subsistence farming system of the middle hills, Nepal. Agriculture, Ecosystems and Environment 84:157-167.

Neupane, R.P., K.R. Shaarma \& G.B. Thapa. 2002. Adoption of agroforestry in the hills of Nepal: a logistic regression analysis. Agricultural Systems 72:177-196.
Orozco, O.L. \& D.L. Lentz. 2005. Poisonous plants and their uses as insecticides in Cajamarca, Peru. Economic Botany 59:166-173.

Parlee, B. \& F. Berkes. 2006. Indigenous knowledge of ecological variability and commons management: a case study on berry harvesting from Northern Canada. Human Ecology 34:515-528.

Poggie, J.J. 1972. Toward quality control in key informant data. Human Organization 31:23-30.

Prance, G.T. 2004. The uses of Atuna racemosa Raf. (Chrysobalanaceae) in Samoa. Economic Botany 58:470475.

Ramihantaniariyo, H., R.F. Ramambazafy \& N. Quansah. 2003. Medicinal plant use in reproductive health disorders. Ethnobotany Research and Applications 1:39-42.

Rew, L.J., B.D. Maxwell, F.L. Dougher \& R. Aspinall. 2006. Searching for a needle in a haystack: evaluating survey methods for non-indigenous plant species. Biological Invasions 8:523-539.

Reyes-Garcia, V., V. Vadez, E. Byron, L. Apaza, W.R. Leonard, E. Perez \& D. Wilkie. 2005. Market economy and the loss of folk knowledge of plant uses: estimates from the Tsimane' of the Bolivian Amazon. Current Anthropology 46:651-683.

Robbins, M.C. \& R.B. Pollnac. 1969. Drinking patterns and acculturation in rural Buganda. American Anthropologist 71:276-285.

Romney, A.K. 1999. Cultural consensus as a statistical model. Current Anthropology 40:S103-S115.

Romney, A.K., S.C. Weller \& W.H. Batchelder. 1986. Culture as consensus: a theory of culture and informant accuracy. American Anthropologist 88:313-338.

Ross, N. \& D.L. Medin. 2005. Effects elicited with experimental research techniques. Field Methods 17:131-149.

Ross-lbarra, J. \& A. Molina-Cruz. 2002. The ethnobotany of chaya (Cnidoscolus aconitifolius ssp. aconitifolius Breckon): a nutritious Maya vegetable. Economic Botany 56:350-365.

Runyoro, D.K.B., O.D. Ngassapa, M.I.N. Matee, C.C. Joseph \& M.J. Moshi. 2006. Medicinal plants used by Tanzanian traditional healers in the management of Candida infections. Journal of Ethnopharmacology 106:158-165.

Saikia, A.P., V.K. Ryakala, P. Sharma, P. Goswami \& U. Bora. 2006. Ethnobotany of medicinal plants used by Assamese people for various skin ailments and cosmetics. Journal of Ethnopharmacology 106:149-157. 
Sanders, I.T. 1960. The community social profile. American Sociological Review 25:75-77.

Seidler, J. 1974. On using informants: a technique for collecting quantitative data and controlling measurement error in organization analysis. American Sociological Review 39:816-831.

Silva, A.J.dR \& L.dH.C. Andrade. 2006. Cultural significance of plants in communities located in the coastal forest zone of the State of Pernambuco, Brazil. Human Ecology 34:447-465.

Smith, T.M.F. 1983. On the validity of inferences from nonrandom sample. Journal of the Royal Statistical Society. Series A (General) 146:394-403.

Snedecor, G.W. 1939. Design of sampling experiments in the social sciences. Journal of Farm Economics 21:846855.

Sundriyal, M. \& R.C. Sundriyal. 2004. Wild edible plants of the Sikkim Himalaya: nutritive values of selective species. Economic Botany 58:286-299.

Tardio, J., H. Pascual \& R. Morales. 2005. Wild food plants traditionally used in the province of Madrid, Central Spain. Economic Botany 59:122-136.

Topp, L., B. Barker \& L. Degenhardt. 2004. The external validity of results derived from ecstasy users recruited using purposive sampling strategies. Drug and Alcohol Dependence 73:33-40.

Tran, V.M. \& J.A. Perry. 2003. Challenges to using neem (Azadirachta indica var. siamensis Valenton) in Thailand. Economic Botany 57:93-102.

Tremblay, M.-A. 1957. The key informant technique: a nonethnographic application. American Anthropologist 59:699-701.

Vargas, M.P.B. \& T. van Andel. 2005. The use of hemiepiphytes as craft fibres by indigenous communities in the Colombian Amazon. Ethnobotany Research and Applications 3:243-260.

Walker, M., J. Nunez, M. Walkingstick \& S.A. Banack. 2004. Ethnobotanical investigation of the Acjachemen clapperstick from blue elderberry, Sambucus mexicana (Caprifoliaceae). Economic Botany 58:21-24.

Zelditch, M.Jr. 1962. Some methodological problems of field studies. The American Journal of Sociology 67:566576.

Zent, S. 2001. Acculturation and ethnobotanical knowledge loss among the Piaroa of Venezuela: Demonstration of a quantitative method for the empirical study of traditional ecological knowledge change. Pp. 190-211 in On Biocultural Diversity: Linking Language, Knowledge, and the Environment. Edited by L. Maffi. Smithsonian Institution Press, Washington D.C.

Zhen, L., M.A. Zoebisch, G. Chen \& Z. Feng. 2006. Sustainability of farmers' soil fertility management practices: A case study in the North China Plain. Journal of Environmental Management 79:409-419. 